experiment has also shown that it would be better to preserve one or two hundred hailstones separate from each other than a greater number of them, but partly-especially in lower layers-frozen together. That can be attained by placing the hailstones in some very viscous liquid $(e . g$. cylinder-oil, vaseline, or castor-oil) of a density nearly equal to that of hail.

For the investigation of the microstructure of a separate hailstone Mr. W. Dudeclii and I made a thin section of it by first rubbing one side on emery-paper or by melting it with the warmth of a finger. This side was laid upon an object-glass and frozen to it, after touching for some time with a finger the other side of the glass. The other side of the hailstone was then polished in the same manner as the first until the requisite thickness was attained. These operations were made in free air, and were so much easier, as the temperature of the air was below $0^{\circ}$. Still, it was found possible to grind hailstones in the laboratory at the temperature of the room by means of cooling the object-glass, the emery-paper, \&c., in double-walled vessels with a mixture of ice and common salt.

For the optical investigation of thin sections in free air a polarising microscope was used, and in a lecture-room a projecting lantern. In the latter case (Fig. 2) the section

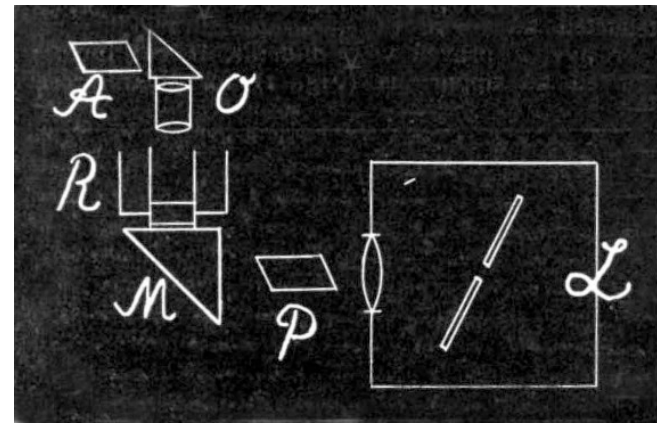

F1G. 2.-L, Projecting lantern ; p', polariser ; $M$, mirror ; $R$, refrigerating vessel; o, objective; $A$, analyser.

was laid in a refrigerating vessel with double walls and double bottom (to avoid the condensation of aqueous vapour from the surrounding air) of plane-parallel glass plates. The space between the walls contained a mixture of ice and common salt. The real image of the section was thrown on a screen or on a photographic ("Autochrom") plate.

The greater part of the hailstones were crystalline individuals, as also was the case with "artificial hailstones"-drops of water frozen in a mixture of cinnamon and linseed oil of suitable density. In those hailstones, which consisted of several crystalline individuals, there was no regularity in the form of the boundaries between crystals, or in the angles between these boundaries, or in the directions of the optical axes, which lay indifferently to each other, as well as to the milky nucleus of the hailstone, which appeared in the section as a number of airbubbles of different size.

I trust that my attempt will cause similar researches to be undertaken, and I should be very glad if anyone who may be able to preserve or study larger or more peculiar hailstones than I have hitherto done will do so, and in this way improve our deficient knowledge on the origin of hail and the details of its formation.

BORIS WEINBERG.

The Physical Laboratory of the Technological

Institute of Tonsk, Russia.

Thoughtless Destruction of Wild Flowers.

MAY I ask through your widely circulated paper that those who organise the weekly or fortnightly visits of poor town children to country villages may be requested to instruct these children to pluck only a limited number of wild flowers? It is no uncommon sight to see a dozen or more of these children going along a road or railway embankment and plucking every flower they can find, as well as rooting up those which are sinall enough. In half an hour the flowers have withered, and are thrown away, when the same process is repeated.

Otford, Kent, May 27.

Geo. Henderson.

NO. 2 I I9, VOL. 83$]$

\section{RECENT PROGRESS IN INDIAN FOREST} TECHNOLOGY.

THE excellence of the work of any public department depends on the character and ability of the men who direct it, and the Indian Forest Department was singularly fortunate in its first InspectorGeneral, the late Sir Dietrich Brandis, K.C.I.E., F.R.S. He secured State ownership and State management for the forests both in British India and in the native States, and also a trained staff of forest officers. He placed Indian forest law on a firm basis by selecting as Conservator of Forests, $\mathrm{Mr}$. B. H. Baden-Powell, C.S.I., a member of the Punjab Civil Service, who, after working for a decade of his life in the forest service, became presiding judge of the chief court at Lahore. Baden-Powell drafted the Indian Forest Acts, models of forest law that are followed by all colonial legislators, and his "Manual of Forest Jurisprudence" is the only English book on the subject. No mere forester could have drafted those laws successfully, nor could any mere lawyer, but Baden-Powell was both lawyer and forester.

Brandis also established a forest survey under Lieut. Colonel F. Bailey, R.E., and Mr. W. H. Reynolds, and their maps gained gold medals at two Paris exhibitions, and were the first Indian maps that showed a good system of contour lines. A forest school for training native members of the provincial and executive staffs of the Forest Department was established in 1881 , at Dehra Dun. Useful manuals of forestry, by Mr. E. E. Fernandez, and of botany, were published soon after the establishment of this school for the use of the students. Brandis also published a Forest Flora of Northern India, followed quite recently by his last great work, "Indian Trees," a forest flora for the whole of India. Mr. Kurz had previously written one for Burma and Major Beddome for Madras, while Mr. J. S. Gamble, C.I.E. F.R.S., published a splendid monograph of Indian bamboos. Gamble, under Brandis's direction, published, in I88I, a "Manual of Indian Timbers," and again, in I90I, after collecting material for twenty years, a new and greatly enlarged and improved edition. "The Indian Forester" first appeared in I876, Dr. Schlich, now Sir W. Schlich, K.C.I.E. F.R.S., being the first editor. Schlich succeeded Brandis as Inspector-General of Forests in $188 \mathrm{r}$, and instituted a proper system of working plans for Indian forests. He came home in 1885 and established a school of forestry at Coopers Hill, and, in conjunction with myself, published a "Manual of Forestry."

The training of men in England for the Indian Forest Service was not at first in accordance with the wishes of Brandis and Schlich. They recommended that the Imperial School of Forestry should be at an English university, and that, as the so-called Civil Service of India is recruited chiefly from university men of good literary and legal attainments, so the Imperial Forest branch of the Civil Service, which manages onequarter of the land of British India, should be composed of university men of good scientific attainments. But the India Office wished to support the Royal Indian Engineering College at Coopers Hill, and kept the forest probationers there until 1905 , the year before the college was closed. In 1905, an Imperial School of Forestry was established at Oxford under Sir William Schlich, and is now training more than seventy men for India, the colonies, and for forest work at home.

Until I904 very little prosress was made in Indian forest technology, for which Brandis had laid such $x$ 
splendid foundation. It was found that the class of candidates for the forest service was falling off in numbers and quality, the salaries were not sufficiently attractive, and in 1905 only two candidates appeared for sixteen posts, so that a system of appointment by selection was adopted. The Secretary of State has now raised the pay of the Indian Forest Service, and allows I2ol. a year to such of the two years' probationers who are B.A.s with honours from any university, so that this year there were sixty candidates for twelve appointments. Besides insisting on the qualification of an honour degree, it is essential to secure that all probationers should join the Oxford School of Forestry, with a sufficient knowledge of English, elementary mathematics (including trigonometry), physics, and chemistry. During the two years' course for a forestry diploma at Oxford, botany, zoology, and geology can be taught, as well as forestry, surveying, and forest law. Strange to say, some of our British universities have such an imperfect entrance examination that men are allowed to enter for and take honour degrees in biology or geology without necessarily knowing more than the rudiments of mathematics, chemistry, or physics, and without passing any test in English. The possession of an honour degree in science at a British university is not, therefore, a sufficient qualification for a forest probationer. A certain knowledge of German also is very desirable for admission to the Oxford School of Forestry, and this is but rarely obtainable from our public-school men. Our best Oxford foresters should be capable of teaching scientific and practical forestry throughout the Empire.

Although the forests of India, between 1885 and I905, continued to be well managed by a devoted corps of practical foresters, very little, if any, progress in forest technology was made during those twenty years. In 1906, Mr. S. Eardley Wilmot, C.I.E., Inspector-General of Forests, following the initiative of his predecessor, Mr. R. C. Wroughton, established $a$ forest research institute the members of which devote all their time to the study of the various branches of forestry, as well as to zoology, mycology, and the physics and chemistry of forest products. The results of this research are published in "Indian Forest Records." Vol. i., for 1909, of these records contains papers on the lac insect, by E. P. Stebbing; on beetles boring in Chilgoza bark, by E. P. Stebbing and Capt. E. H. James; the development of Shorea robusta in volume and money value, and the selection system in Indian forests, by A. M. F. Caccia; Andaman Padank, by B. B. Osmaston; the Cutch trade of Burma, by $R$. S. Troup; Ngai camphor, and Burmese varnish from the sap of Melanorrhoea usitata, by Puran Singh. Several useful and, for the most part, elementary manuals have been prepared by members of the Research Institute and others, the most elaborate of which are "Indian Forest Engineering," by G. M. Rogers, and "Indian Forest Zoology," by E. P. Stebbing.

Unfortunately, the establishment of this institute was followed by a temporary deterioration of the teaching staff in Dehra Dun, for the Government of India did not accept Mr. Wilmot's proposal to retain an adequate staff of instructors there, but handed over the practical teaching to the provincial staff, the research officers considering that their other duties would not allow them time to teach the students. The Dehra Dun Forest School, recently dignified with the title of Imperial Forest College, was overcrowded with students, 120 applications for admission having been received in I909, and the students had not sufficient respect for their native teachers, so that discipline suffered greatly.

NO. 2 I I9, VOL. 83]
The Indian Universities Act of I894, which has exerted its influence so widely on higher studies, has failed to reach Dehra. Engineering, medicine, and agriculture, and science generally, have made great advances of late in response to the stimulus of university reform, but at the Imperial Forest College the qualifying entrance examination is still much the same as when it was a school, and its courses still include an amount of rudimentary science that should have no place at a college. This becomes evident when the standards there are compared with those at the agricultural colleges recently established in the various provinces of India. The final examination for the diploma in forestry at Dehra should also be equivalent to those for a B.A. degree, as is the case at agricultural colleges.

The present Inspector-General of Forests, Mr. F. Beadon Bryant, has recognised that the teaching of forest rangers has fallen off since the Research Institute was started, and that it was a mistake to entrust the teaching of classes of sixty students there to members of the provincial service. Research officers in future will give lectures to the students during the four months' monsoon session, and three officers of the Imperial Forest Service are being appointed to teach the students throughout the two years' course for rangers and the three years' course for the provincial staff. Overcrowding at Dehra is to be avoided by the establishment of a school for rangers in the Madras Presidency, with at least two professors from the Imperial staff, and probably another school on similar lines will be established in the Central Provinces. Indian forest schools have to provide foresters for Kashmir, Mysore, Hyderabad, and the other native States, besides for British India, and $\mathrm{Mr}$. Wilmot has recently been deputed to Nepal to organise a suitable forestry department there.

It is evident that schools of forestry, at home, in India, and in the colonies, must be in close touch with the universities; but while Indian universities have a suitable English and scientific entrance examination, this is not yet the case with some of our most important home universities, and this defect calls loudly for reform in the best interests of our Empire. The prospects of forest technology in India are now very high, and it is to be hoped that, following the example there and that of South Africa, where a forest school has been established, the Dominion of Canada, Newfoundland, Australia, and New Zealana will soon bestow sufficient attention on forestry and establish local forest schools. Besides India and South Africa, the scientific forestry of which has been long established, there are regular forestry departments in Ceylon, the Malay States, the Soudan, British East Africa, Mauritius, Cyprus, and in some of the West Indian Islands.

W. R. FISHER.

\section{THE TWENTIETH-CENTURY SPORTSMAN.'}

THIS amazing picture-book (recommendable, among a hundred other reasons, in that, though large in size, it is very light to hold in the hand) will probably faire école. That it has made a sensation amongst the reading public interested in Africa is already observable by the reviews of it which have appeared in the leading newspapers, and the vogue it has attained in spite of the conflicting interest of current politics. This is little to be wondered at. The author (who is the brother of the Captain W. R. Dugmore who distinguished himself in Uganda and elsewhere as a soldier-pioneer) had, no doubt, supreme

I "Camera Adventures in the African Wilds; being an Account of a Four Months' Expedition in Pritish East Africa, for the Purpose of Securing Photographs from Life of the Game." By A. Radiclyffe Dugmore. Pp. xviiit 23 r. (London: William Heinemann, rgro ) Price 305 . net. 